Glosses

Studia Iuridica Lublinensia vol. XXIX, 1, 2020

DOI: $10.17951 /$ sil.2020.29.1.307-320

\title{
Paulina Zadykowicz
}

Uniwersytet w Białymstoku, Polska

ORCID: 0000-0001-6611-8691

zadykowicz.paulina@gmail.com

\section{Glosa do wyroku Naczelnego Sądu Administracyjnego z dnia 25 kwietnia 2018 r. (II GSK 2337/16)}

\author{
Gloss to the Judgement of the Supreme Administrative Court \\ of 25 April 2018 (II GSK 2337/16)
}

\section{STRESZCZENIE}

Przedmiotem niniejszej glosy jest wyrok Naczelnego Sądu Administracyjnego w sprawie o nałożenie administracyjnej kary pieniężnej za przejazd pojazdem nienormatywnym, którym uchylono wyrok Wojewódzkiego Sądu Administracyjnego w Warszawie i przekazano sprawę do ponownego rozpoznania. W orzeczeniu tym skład orzekający, idąc niejako na przekór dotychczasowej linii orzeczniczej, stwierdził, iż odkodowanie znaczenia „nacisku osi przewidzianego dla danej drogi” może być wynikiem zastosowania wykładni funkcjonalnej, a co za tym idzie podstawą do jego ustalenia może być również rozporządzenie Ministra Infrastruktury z dnia 31 grudnia 2002 r. w sprawie warunków technicznych pojazdów oraz zakresu ich niezbędnego wyposażenia. Treść samej sentencji oraz uzasadnienia do orzeczenia nie pozwala na zaaprobowanie tego wyroku, dlatego glosa ma charakter krytyczny.

Słowa kluczowe: pojazd nienormatywny; nacisk osi; przepisy o drogach publicznych; Prawo o ruchu drogowym

\section{WPROWADZENIE}

Drogi publiczne, jako kategoria szczególnych rzeczy publicznych mających niebagatelne znaczenie dla realizacji zadań administracji publicznej, w szczególności w zakresie transportu i przemieszczania się, mogą być jednocześnie przedmiotem 
użytkowania zwykłego i szczególnego'1. Z uwagi na funkcję komunikacyjną przypisywaną drogom publicznym powszechność korzystania $\mathrm{z}$ nich wiąże się $\mathrm{z}$ wyrażonym w art. 52 ust. 1 i 2 Konstytucji $\mathrm{RP}^{2}$ prawem do swobodnego poruszania się na terytorium Rzeczypospolitej Polskiej oraz przekraczania granic państwowych ${ }^{3}$. Odnosi się ona do wszystkich kategorii dróg publicznych wymienionych w ustawie z dnia 21 marca 1985 r. o drogach publicznych ${ }^{4}$, które służą interesowi wszystkich użytkowników danej drogi ${ }^{5}$. Wskazuje się, że powszechność dostępu sprowadza się do dopuszczenia korzystania z drogi publicznej przez każdego, kto ma zamiar przemieszczania się na terytorium Polski bez wymogu uprzedniego uzyskania zgody organu reprezentującego właściciela tej drogi ${ }^{6}$. Dlatego też dostępu tego nie można ograniczać z uwagi na rodzaj podmiotu poruszającego się po drodze, zapewniając jednakowe warunki zarówno osobom fizycznym, osobom prawnym, podmiotom publicznym i prywatnym, obywatelom polskim, jak i cudzoziemcom. Co więcej, z drogi publicznej korzystać można tylko zgodnie z jej przeznaczeniem. Z uwagi na to nieuzasadnione byłoby objęcie ochroną przewidzianą dla powszechnego dostępu sytuacji, w których podmiot dopuszcza się na drodze aktywności sprzecznych z prze-

1 W piśmiennictwie wskazuje się na różne dopuszczalne sposoby korzystania z dóbr publicznych. Klasyczną klasyfikację zaproponował S. Kasznica (Polskie prawo administracyjne, Poznań 1946, s. 148 i n.), który wyróżnił korzystanie: zwykłe (wynikające z właściwości danego dobra i celu, któremu ma służyć), wzmocnione (korzystanie w zakresie szerszym aniżeli w przypadku zwykłego, przy czym wymaga ono uzyskania pozwolenia wydawanego na czas określony, które może zostać „odwołane”) oraz specjalne (intensywniejsze niż wzmocnione, przejawiające charakter trwały, powodujące zmianę w substancji dobra publicznego oraz w pewnym zakresie ograniczające zwykłe korzystanie). Obecnie wskazuje się na dwa możliwe sposoby korzystania: powszechne (zwyczajne) oraz szczególne (por. D.R. Kijowski, Pozwolenia w administracji publicznej, Białystok 2000, s. 109). Na podział taki wskazał również P. Zaborniak w monografii Prawo dostępu do dóbr publicznych (Warszawa 2015). Zauważa się, że dobra publiczne przeznaczone są do powszechnego korzystania, kiedy w świetle obowiązującego prawa dopuszczalne jest dysponowanie nimi przez każdego zgodnie z ich przeznaczeniem, bez konieczności uzyskiwania w tym celu jakiejkolwiek zgody (por. D.R. Kijowski, [w:] System Prawa Administracyjnego, t. 7: Prawo administracyjne materialne, red. R. Hauser, Z. Niewiadomski, A. Wróbel, Warszawa 2017, s. 448 i n.). Natomiast szczególne korzystanie z dóbr publicznych sprowadzać się ma do wykroczenia poza granice powszechnego korzystania, co jednocześnie wymaga uzyskania zgody organu administracji publicznej (por. P. Zaborniak, Prawo dostępu..., s. 254).

2 Konstytucja Rzeczypospolitej Polskiej z dnia 2 kwietnia 1997 r. (Dz.U. nr 78, poz. 483 ze zm.).

3 P. Zaborniak, Ustawa o drogach publicznych. Komentarz, Warszawa 2010, s. 21.

4 T.j. Dz.U. 2018, poz. 2068 ze zm., dalej: u.d.p.

5 Wyrok WSA w Kielcach z dnia 16 czerwca 2011 r., II SA/Ke 247/11, Legalis nr 377213. W uzasadnieniu do wyroku skład orzekający zwrócił uwagę, że drogi publiczne formalnie należące do jednostek samorządu terytorialnego nie są budowane i utrzymywane tylko i wyłącznie w ich interesie, lecz w interesie wszystkich użytkowników danej drogi publicznej.

6 K. Sobieralski, Kara za zajęcie pasa drogowego, Wrocław 2015, s. 34, P. Zaborniak, Ustawa..., s. 20. 
widzianym dla niej przeznaczeniem ${ }^{7}$. Niemniej w niektórych przypadkach wykonywanie ruchu po drodze publicznej zostało poddane reglamentacji z uwagi na potrzebę ich ochrony przed różnego rodzaju zniszczeniami, uszkodzeniami, zmniejszeniem trwałości czy zagrożeniem w ruchu drogowym ${ }^{8}$. Przejawem takiego ograniczenia jest regulowanie ruchu pojazdów nienormatywnych po drogach publicznych.

Przedmiotem niniejszej glosy jest wyrok Naczelnego Sądu Administracyjnego w sprawie o nałożenie administracyjnej kary pieniężnej za przejazd pojazdem nienormatywnym, którym uchylono wyrok Wojewódzkiego Sądu Administracyjnego w Warszawie i przekazano sprawę do ponownego rozpoznania. Treść samej sentencji oraz uzasadnienia do orzeczenia NSA nie pozwala na jego zaaprobowanie.

\section{P. Zaborniak, Ustawa o drogach publicznych..., s. 22.}

8 Zarówno w przepisach u.d.p., jak i w przepisach odrębnych znaleźć można różnorodne przypadki, w których ustawodawca ogranicza powszechne korzystanie z dróg publicznych. Po pierwsze, zgodnie z art. 3 u.d.p. wyróżnić można drogi o ograniczonej dostępności, do których ustawodawca zalicza w szczególności drogi ekspresowe oraz autostrady. Ograniczenie w tym przypadku sprowadza się do dopuszczenia do ruchu po takiej drodze tylko określonych kategorii pojazdów (tzn. zgodnie z art. 4 pkt 10 i 11 u.d.p. w zw. z art. 3 pkt 33 p.r.d. pojazdów silnikowych, których konstrukcja umożliwia jazdę z prędkością przekraczającą $25 \mathrm{~km} / \mathrm{h}$, z wyłączeniem ciągników rolniczych), a w niektórych sytuacjach może odnosić się do odpłatności za przejazd. Zasady pobierania opłat za przejazd na autostradach płatnych zostały określone w ustawie z dnia 27 października 1997 r. o autostradach płatnych i Krajowym Funduszu Drogowym (Dz.U. 2017, poz. 1057 z późn. zm.), natomiast wykaz płatnych autostrad znajduje się w rozporządzeniu Rady Ministrów z dnia 16 lipca 2002 r. w sprawie autostrad płatnych (Dz.U. 2014, poz. 45). Korzystanie z drogi publicznej może zostać ograniczone również z uwagi na wyrażenie przez zarządcę drogi zgody na korzystanie z niej w sposób szczególny. W takiej sytuacji wydawane jest czasowe pozwolenie na zajęcie pasa drogowego, o którym jest mowa w art. 40 u.d.p. Wiele ograniczeń i wyjątków w korzystaniu z dróg publicznych odnaleźć można w p.r.d., gdzie w sposób szczegółowy uregulowano kwestie związane z zasadami ruchu po drogach publicznych osób, pojazdów (w tym odnoszące się do warunków dopuszczenia pojazdu do jazdy) i zwierząt oraz odnoszące się do zasad korzystania z dróg publicznych. Innym przykładem ograniczenia dostępu do dróg publicznych jest rozporządzenie Ministra Transportu z dnia 31 lipca 2007 r. w sprawie okresowych ograniczeń oraz zakazu ruchu niektórych rodzajów pojazdów na drogach (Dz.U. 2013, poz. 839), zgodnie z którym ruch pojazdów o dopuszczalnej masie całkowitej przekraczającej 12 ton (z wyłączeniem autobusów) jest ograniczony w godzinach i dniach szczegółowo w nim wykazanych. Co więcej, do ograniczeń w powszechności dostępu zalicza się również reglamentowanie korzystania z dróg publicznych w celach zarobkowych. Ustawa z dnia 6 września 2001 r. o transporcie drogowym (t.j. Dz.U. 2017, poz. 2200 ze zm.) nakłada m.in. obowiązek uzyskania: stosownej licencji wspólnotowej (art. 5a), jeżeli przedsiębiorca posiadający zezwolenie na wykonywanie zawodu przewoźnika drogowego chce podjąć i wykonywać międzynarodowy transport drogowy, bądź stosownej licencji (art. 5b), jeżeli przedsiębiorca ma zamiar podjąć i wykonywać krajowy transport drogowy w zakresie przewozu osób samochodem osobowym, pojazdem samochodowym przeznaczonym konstrukcyjnie do przewozu powyżej 7 i nie więcej niż 9 osób łącznie z kierowcą lub taksówką, czy też transport drogowy w zakresie pośrednictwa przy przewozie rzeczy. Inne przykłady ograniczeń powszechnego dostępu do dróg publicznych odnaleźć można również w art. 173-179 ustawy z dnia 27 kwietnia 2001 r. - Prawo ochrony środowiska (t.j. Dz.U. 2018, poz. 799 ze zm.) oraz w ustawie z dnia 19 sierpnia 2011 r. o przewozie towarów niebezpiecznych (t.j. Dz.U. 2019, poz. 382). 
Co więcej, poglądy wyrażone przez skład orzekający w glosowanym wyroku mogą budzić uzasadnione wątpliwości, gdyż stanowią wyłom w dotychczas wypracowanej linii orzeczniczej. Z uwagi na ograniczone ramy niniejszej glosy analizie nie zostały poddane podniesione w sprawie kwestie odnoszące się do sposobu ustalania rzeczywistej masy całkowitej pojazdu za pomocą wag typu SAW 10C/II.

\section{STAN FAKTYCZNY}

Decyzją z 2015 r. Wojewódzki Inspektor Transportu Drogowego nałożył na spółkę A. sp.j. w oparciu o art. 140aa ust. 1 i 3 oraz art. 140ab ust. 1 pkt 3 w zw. $\mathrm{z}$ art. $140 \mathrm{ab}$ ust. 2 ustawy z dnia 20 czerwca 1997 r. - Prawo o ruchu drogowym ${ }^{9}$ administracyjną karę pieniężną za przejazd pojazdem nienormatywnym po drodze powiatowej (w wyniku rutynowej kontroli inspektorzy Inspekcji Transportu Drogowego ustalili, iż pojazd ciężarowy przewożący ładunek podzielny w postaci kruszywa przekroczył nacisk na podwójnej osi napędowej o 10,27\% oraz rzeczywistą masę całkowitą o 7,34\%). Spółka od niniejszej decyzji wniosła odwołanie do Głównego Inspektora Transportu Drogowego, który utrzymał ją w mocy.

Ukarana spółka wywiodła skargę do Wojewódzkiego Sądu Administracyjnego w Warszawie, który uchylił zaskarżoną decyzję oraz utrzymującą ją w mocy decyzję organu pierwszej instancji. Skład orzekający wskazał, iż w stanie faktycznym będącym podstawą rozstrzygnięcia przedmiotowy pojazd nie spełniał przesłanek umożliwiających zaliczenie go do kategorii pojazdów nienormatywnych, które zostały wskazane w art. 2 pkt 35a p.r.d. Definicja ta bowiem zdaniem sądu pierwszej instancji w sformułowaniu ,naciski osi [...] są większe od dopuszczalnych, przewidzianych dla danej drogi w przepisach o drogach publicznych" odsyła do przepisów u.d.p., w których ustawodawca ustanowił tylko i wyłącznie normy maksymalnych nacisków osi pojedynczych. Podniósł on również, iż u.d.p. ani żaden akt wykonawczy wydany na jego podstawie nie reguluje w żaden sposób kwestii nacisku osi wielokrotnych (dlatego odniesienie wartości ich rzeczywistego nacisku do wartości przewidzianych dla danej drogi w przepisach o drogach publicznych jest niemożliwe). Z uwagi na to niedopuszczalna jest rozszerzająca wykładnia art. 2 pkt 35a p.r.d. poprzez uwzględnienie jako podstawy ustalenia normy nacisku osi wielokrotnej na drogę przepisów rozporządzenia Ministra Infrastruktury z dnia 31 grudnia 2002 r. w sprawie warunków technicznych pojazdów oraz zakresu ich niezbędnego wyposażenia ${ }^{10}$, gdyż akt ten służy przede wszystkim określeniu warunków technicznych pojazdów niezbędnych na etapie ich rejestracji, a przekroczenie norm w nim wskazanych nie czyni pojazdu nienormatywnym.

9 T.j. Dz.U. 2018, poz. 1990 ze zm., dalej: p.r.d.

10 T.j. Dz.U. 2016, poz. 2022 ze zm., dalej: r.w.t. 
Od wyroku Wojewódzkiego Sądu Administracyjnego w Warszawie skargę kasacyjną wywiódł Główny Inspektor Transportu Drogowego, zaskarżając go w całości. W skardze wniósł o uchylenie wydanego orzeczenia w całości oraz przekazanie sprawy do ponownego rozpoznania sądowi pierwszej instancji.

Skarżący kasacyjnie zarzucił naruszenie zarówno przepisów postępowania, jak i przepisów prawa materialnego. Pierwszy z zarzutów odnosił się do błędnego przyjęcia przez sąd pierwszej instancji, iż stan faktyczny sprawy został ustalony w nieprawidłowy sposób poprzez niewłaściwe określenie zakresu odpowiedzialności ukaranej spółki, przy czym w opinii skarżącego organy załatwiające sprawę przyjęły prawidłowe podstawy do ustalenia nienormatywności pojazdu. Drugi z zarzutów dotyczył niewłaściwej wykładni przejawiającej się w przyjęciu przez sąd pierwszej instancji, iż w obecnie obowiązującym stanie prawnym nie można uznać za nienormatywny pojazdu, którego naciski osi wielokrotnych są większe od dopuszczalnych wskazanych w r.w.t., a co za tym idzie błędne odkodowanie znaczenia sformułowania „przepisy o drogach publicznych”, którymi posłużył się ustawodawca w art. 2 pkt 35a p.r.d. Uzasadniając swoje stanowisko, skarżący kasacyjnie podniósł, iż przepisy mające zastosowanie w przedmiotowej sprawie są zbieżne z przepisami dyrektywy Rady nr 96/53/WE z dnia 25 lipca 1996 r. ustanawiającej dla niektórych pojazdów drogowych poruszających się na terytorium Wspólnoty maksymalne dopuszczalne wymiary w ruchu krajowym i międzynarodowym oraz maksymalne dopuszczalne obciążenia w ruchu międzynarodowym ${ }^{11}$. $\mathrm{Z}$ uwagi na to nie można kategorycznie stwierdzić, iż przepisy r.w.t. służą jedynie celom rejestracji pojazdów, skoro parametry te (zgodnie z treścią dyrektywy 96/53) ustalać mają przede wszystkim parametry dla pojazdów, które uczestniczą w ruchu drogowym na drogach publicznych. W odpowiedzi na niniejszą skargę ukarana spółka wniosła o jej oddalenie.

Naczelny Sąd Administracyjny uchylił zaskarżony wyrok i przekazał sprawę do ponownego rozpoznania Wojewódzkiemu Sądowi Administracyjnemu w Warszawie. Skład orzekający, podważając stanowisko sądu pierwszej instancji, stwierdził, iż odkodowanie znaczenia definicji „pojazdu nienormatywnego” wymaga wykorzystania wykładni funkcjonalnej, gdyż sformułowanie ,przepisy o drogach publicznych", którym posłużył się ustawodawca w art. 2 pkt 35a p.r.d., nie jest całkowicie jednoznaczne. $Z$ tego względu zdaniem NSA do ,przepisów o drogach publicznych" z powodzeniem zaliczyć można zarówno u.d.p. oraz p.r.d., jak i akty wykonawcze wydane na ich podstawie (w tym r.w.t.). Skład orzekający NSA podniósł, iż za takim wynikiem wykładni art. 2 pkt 35a p.r.d. przemawia charakter przepisów r.w.t., które w szczególności w odniesieniu do dopuszczalnych nacisków osi pojazdów implementują dyrektywę 96/53, a co za tym idzie są normami transportowymi i odnoszą się do warunków załadunku, nie zaś do norm produkcji.

\footnotetext{
${ }^{11}$ Dz.Urz. UE L nr 235, s. 59, dalej: dyrektywa 96/53.
} 
Dodatkowo zdaniem sądu drugiej instancji niedopuszczalne jest uznawanie r.w.t. wyłącznie jako aktu określającego warunki techniczne pojazdów, którym powinny odpowiadać na etapie dopuszczania ich do ruchu, ponieważ przepisy te zachowują nadany im sens, kiedy są stosowane i egzekwowane w stosunku do pojazdów biorących udział w ruchu drogowym. Do wyroku zgłoszone zostało zdanie odrębne, którego autor nie zgodził się z rozstrzygnięciem oraz uzasadnieniem wyroku NSA i jednocześnie przychylił się do argumentacji sądu pierwszej instancji.

\section{KOMENTARZ}

W języku potocznym pod pojęciem ,pojazd” rozumie się każdy środek lokomocji, który przystosowany jest do poruszania się na kołach, gąsienicach, płozach czy bezpośrednio na gruncie ${ }^{12}$. Niemniej p.r.d. pojęcie to definiuje odrębnie (art. 2 pkt 31 p.r.d.), wskazując, iż jest to środek transportu przeznaczony do poruszania się po drodze oraz maszyny lub urządzenia do tego przystosowane ${ }^{13}$. Szczególnym rodzajem pojazdu jest pojazd nienormatywny, za który uznaje się pojazd bądź zespół pojazdów ${ }^{14}$, którego naciski wraz z ładunkiem lub bez ładunku są większe od dopuszczalnych, przewidzianych dla danej drogi w przepisach o drogach publicznych lub którego wymiary lub rzeczywista masa całkowita wraz z ładunkiem lub bez niego są większe od dopuszczalnych przewidzianych w przepisach p.r.d. ${ }^{15}$

${ }_{12}$ Zob. Mały słownik języka polskiego, red. S. Skorupka, H. Auderska, Z. Łempicka, Warszawa 1969, s. 590.

${ }_{13}$ Do kategorii tej prawodawca zalicza zarówno pojazdy silnikowe (art. 2 pkt 32 p.r.d. - pojazdy samochodowe, w tym samochody osobowe, ciężarowe, autobusy, czterokołowe, motocykle; ciągniki rolnicze, pojazdy wolnobieżne), jak i motorowery (art. 2 pkt 46 p.r.d.), a także przyczepy (art. 2 pkt 50 p.r.d.).

14 Zgodnie z art. 2 pkt 49 p.r.d. zespołem pojazdów są pojazdy złączone ze sobą w celu poruszania się po drodze jako całość ( $\mathrm{z}$ wyłączeniem pojazdów łączonych ze sobą celem holowania). Zespoły mogą składać się maksymalnie z 3 pojazdów, natomiast w przypadku gdy zespół ciągnięty jest przez pojazd silnikowy, pojazd wolnobieżny lub ciągnik rolniczy - maksymalnie z 2 pojazdów.

${ }^{15}$ Pierwszym kryterium nienormatywności pojazdu jest dopuszczalny nacisk osi. Wydawać by się mogło, iż wybór takiego kryterium nie powinien budzić wątpliwości. Jak słusznie zauważono: „[...] ustawodawca uznał, że największe spustoszenie na drogach czynią pojazdy o niewłaściwym, nierównomiernym rozłożeniu ładunku na poszczególne osie, a decydującym czynnikiem oceny normatywności pojazdu muszą być w istocie naciski wywierane właśnie na poszczególne osie pojazdu. Dlatego też przekroczenie dopuszczalnej normy na choćby jednej z osi napędowych powinno być karane. Jest to podyktowane dbałością o ochronę stanu technicznego dróg, jako że przeciążenie chociażby jednej z osi ponad dopuszczalną wartość techniczną drogi może skutkować negatywnie na jej stan [...], a pojazd uczestniczący w ruchu ma być tak zbudowany, wyposażony i utrzymany, aby korzystanie z niego nie powodowało niszczenia drogi" (zob. wyrok WSA w Warszawie z dnia 12 kwietnia 2017 r., VI SA/Wa 2679/16, Legalis nr 1603416). Drugim kryterium decydującym o nienormatywności pojazdu jest rzeczywista masa całkowita bądź wymiary pojazdu lub zespołu 
Jak słusznie zauważył skład orzekający NSA w glosowanym orzeczeniu, to właśnie odkodowanie pojęcia „pojazdu nienormatywnego” jest kluczowe dla ustalenia odpowiedzialności za delikt administracyjny wskazany w art. 140aa p.r.d., przy czym sposób jego rozumienia przyjęty w przedmiotowej sprawie nie zasługuje na aprobatę. Naczelny Sąd Administracyjny wskazał bowiem, iż sformułowanie ,przepisy o drogach publicznych", którym posłużył się ustawodawca w art. 2 pkt 35a p.r.d., winno być interpretowane za pomocą dyrektyw wykładni funkcjonalnej (odwołując się do wartości oraz celów, jakie można przypisać prawodawcy ustanawiającemu taką, a nie inną regulację), gdyż jest ono nieostre i nieprecyzyjne. Z jednej strony trudno odmówić jako takiej trafności temu poglądowi. Jeżeli przedmiotem rozważań miałyby zostać „przepisy o drogach publicznych” sensu largo, to niewątpliwie zaliczyć do nich można z powodzeniem zarówno u.d.p. oraz p.r.d., jak i akty wykonawcze wydane na ich podstawie - akty te wzajemnie się przenikają i uzupełniają, odnosząc się do szeroko pojmowanej organizacji ruchu drogowego i bezpieczeństwa w granicach dróg publicznych. Jednakże skład orzekający NSA, ustalając znaczenie sformułowania ,przepisy o drogach publicznych” (bądź odnosząc się do niego), pomija zupełnie poprzedzający to stwierdzenie w art. 2 pkt 35a p.r.d. zwrot ,przewidzianych dla danej drogi”, na co słusznie zwrócono uwagę w zdaniu odrębnym. Z uwagi na to wydawać by się mogło, iż skład NSA rozpatrujący przedmiotową sprawę dopuścił się błędu pars pro toto, gdyż ustalił znaczenie normy prawnej w oparciu o część przepisu, nie zaś o jego całość. Zauważyć należy, iż literalne znaczenie sformułowania „przewidziane dla danej drogi" niewątpliwie odsyła do przepisów, w których ustawodawca wskazał, jakie normy nacisku obowiązują w odniesieniu do konkretnej drogi publicznej zgodnie $\mathrm{z}$ ich klasyfikacją wskazaną $\mathrm{w}$ art. 2 ust. 1 u.d.p. ${ }^{16}$ Natomiast takie rozumowanie wręcz wymusza zastosowanie art. 41 u.d.p., w którym prawodawca określił normy nacisków pojedynczych osi napędowych na drogi znajdujące się w sieci dróg publicznych ${ }^{17}$. Dlatego Naczelny Sąd Administracyjny niejako dopuścił się

\footnotetext{
pojazdów. Rzeczywistą masą całkowitą pojazdu (art. 2 pkt 55 p.r.d.) jest jego masa (własna) wraz ze znajdującymi się na nim rzeczami lub osobami. Natomiast wymiary pojazdu różnić się będą w zależności od rodzaju czy podrodzaju pojazdu. Podstawą do ustalenia dopuszczalnych wymiarów czy rzeczywistej masy pojazdu mogą być wyłącznie postanowienia samego p.r.d. oraz wydanych na jego podstawie aktów wykonawczych (w szczególności r.w.t.).

${ }^{16}$ W sieci dróg publicznych wyróżnia się: drogi krajowe, drogi wojewódzkie, drogi powiatowe, drogi gminne. Poza siecią tą znajdują się drogi wewnętrzne.

17 Taki sam pogląd został wyrażony w zdaniu odrębnym do glosowanego wyroku NSA: „,...] w zakresie dopuszczalnych nacisków osi ustawodawca odsyła do »przepisów przewidzianych dla danej drogi« zawartych w przepisach o drogach publicznych. [...] Przepisy, do których odsyła art. 2 pkt 35a p.r.d., to regulacje znajdujące się w u.d.p. i w aktach wykonawczych do tej ustawy. U.d.p. problematykę nacisku osi ujmuje wyłącznie w przepisach art. 41”.
} 
naruszenia zakazu wykładni per non est ${ }^{18}$, ustalając znaczenie pewnego zwrotu $\mathrm{z}$ całkowitym pominięciem sformułowań, które znajdują się w tej samej jednostce redakcyjnej, a nawet w tym samym zdaniu. Co więcej, wydaje się, że przeciw rozumowaniu składu orzekającego NSA świadczy również dotychczas wypracowana linia orzecznicza w przedmiotowej materii. Sądy administracyjne zauważały, iż określenie górnych wartości nacisków dopuszczonych przez prawodawcę dla danej drogi może odbyć się wyłącznie w oparciu o przepisy u.d.p., gdyż żaden inny akt prawny nie odnosi się do problematyki nacisków osi w odniesieniu do konkretnego typu drogi ${ }^{19}$. Wskazywano również, iż „o tym, jakie pojazdy mogą poruszać się po danej drodze, nie decydują przepisy określające maksymalne dopuszczalne naciski osi pojazdów dopuszczonych do ruchu, lecz wartość techniczna tej drogi"’20. Zarzut błędnej wykładni, której dopuścił się NSA, wydaje się uzasadniać także historyczna wykładnia definicji ,pojazdu nienormatywnego”. W uzasadnieniu wyroku NSA słusznie przypomina, iż przepisy regulujące ruch pojazdów nienormatywnych, system zezwoleń na ich prowadzenie oraz odpowiedzialność administracyjną z tego tytułu do 18 października 2012 r. znajdowały się w u.d.p. i dopiero później zostały przeniesione do p.r.d. Zgodnie z regulacją u.d.p. obowiązującą do dnia 18 października 2012 r. pojazdem nienormatywnym był pojazd lub zespół pojazdów, którego „naciski [...] są większe od dopuszczalnych, przewidzianych dla danej drogi w przepisach niniejszej ustawy"21. Z uwagi na to wnioskować można, iż ustawodawca, przenosząc definicję z u.d.p. do p.r.d. i przekształcając sformułowanie ,przepisy niniejszej ustawy” na „przepisy o drogach publicznych”, chciał, aby organy stosujące tę normę, ustalając zaistnienie przesłanki przekroczenia maksymalnych nacisków osi, w danym stanie faktycznym nadal posiłkowały się regulacją u.d.p., nie zaś p.r.d.

W przedmiotowej sprawie nie mniej istotny jest fakt, iż rozważane przepisy odnoszą się do wymierzenia administracyjnej kary pieniężnej. W doktrynie prawa administracyjnego podnosi się, iż pociągnięcie do odpowiedzialności administracyjnej z tytułu dopuszczenia się deliktu administracyjnego powinno mieć swoje podstawy w przepisach spełniających konstytucyjne standardy określoności ${ }^{22}$.

${ }^{18}$ Zgodnie $\mathrm{z}$ tą zasadą interpretator tekstu prawnego nie powinien ustalać znaczenia jakiejś reguły w taki sposób, by pewne jej części były traktowane jako zbędne. Por. M. Zirk-Sadowski, [w:] System Prawa Administracyjnego, t. 4: Wyktadnia w prawie administracyjnym, red. R. Hauser, Z. Niewiadomski, A. Wróbel, Warszawa 2012, s. 201-202.

19 Por. m.in. wyrok NSA z dnia 23 marca 2016 r., II GSK 2172/14, Legalis nr 1509704; wyrok NSA z dnia 18 lipca 2017 r., II GSK 2670/15, Legalis nr 1663997.

${ }^{20}$ Wyrok NSA z dnia 1 lutego 2018 r., II GSK 3289/17, Legalis nr 1757741. Podobnie wyrok NSA z dnia 12 października 2017 r., II GSK 3692/15, Legalis nr 1698684.

${ }^{21}$ Zob. art. 4 pkt 25 u.d.p. w brzmieniu obowiązującym do dnia 18 października 2012 r. (t.j. Dz.U. 2007, poz. 115 ze zm.).

${ }^{22}$ D.K. Nowicki, S. Peszkowski, Kilka uwag o szczególnym charakterze administracyjnych kar pieniężnych, [w:] Administracyjne kary pieniężne w demokratycznym państwie prawa, red. M. Bła- 
Z uwagi na to wątpliwości budzić może wykładnia rozszerzająca, z której skorzystał skład orzekający w glosowanym orzeczeniu ${ }^{23}$. Należy zwrócić uwagę, że zgodnie z przywołanym wcześniej art. 41 u.d.p. co do zasady po drogach publicznych poruszać się mogą pojazdy o dopuszczalnym maksymalnym nacisku pojedynczej osi napędowej wynoszącym 11,5 tony (ust. 1). Jednocześnie ustawodawca dopuścił odstępstwa od tej zasady, wskazując, iż w stosunku do niektórych dróg krajowych i wojewódzkich możliwe jest ustanowienie ograniczeń tonażowych do 10 lub 8 ton (ust. 2), a w stosunku do wszystkich dróg powiatowych i gminnych oraz dróg wojewódzkich innych niż wskazane w rozporządzeniu ustanawia się ograniczenie tonażowe do 8 ton (ust. 3). Jednakże bez względu na to, jaki konkretnie nacisk dopuszczono dla danej drogi, to zgodnie ze wskazaną regulacją zawsze odnosić się on będzie do pojedynczej osi napędowej. Dlatego też, przychylając się do poglądów wyrażonych w zdaniu odrębnym, zauważyć należy, iż aktualnie obowiązujące przepisy regulujące przedmiotową problematykę nie przewidują możliwości pociągania do odpowiedzialności administracyjnej z tytułu przekroczenia nacisku osi innych niż pojedyncze osie napędowe. Za nieuzasadnione należy uznać twierdzenia NSA, że przepisy r.w.t. mogłyby stanowić podstawę do ustalenia maksymalnych dopuszczalnych nacisków osi wielokrotnych na drogi publiczne. Rozporządzenie to, mimo wskazania pewnych norm tonażowych w stosunku do osi napędowych, nienapędowych, pojedynczych oraz wielokrotnych, nie ustanawia ich dla konkretnych dróg (tak jak wymaga tego art. 2 pkt 35a p.r.d.), lecz dla wszystkich pojazdów jako pewien wymóg techniczny, który musi zostać spełniony przez każdy pojazd wyposażony w taką oś. $Z$ tego powodu o ukaraniu powinno przesądzać to, czy pojazd w danym stanie faktycznym przekroczył dopuszczalne obciążenie przewidziane dla danej drogi (zgodne z jego wartością techniczną), które zostało uregulowane

chucki, Warszawa 2015, s. 21-26; M. Król-Bogomilska, Administracyjne kary pieniężne - kierunki rozwoju, [w:] Prawo wobec problemów spolecznych. Księga jubileuszowa Profesor Eleonory Zielińskiej, red. B. Namysłowska-Gabrysiak, K. Syroka-Marczewska, A. Walczak-Żochowska, Warszawa 2016, s. 195-198; G. Wierczyński, Redagowanie i ogłaszanie aktów normatywnych. Komentarz, Warszawa 2016, s. 525-526. Trybunał w licznych orzeczeniach wypowiadał się co do treści powołanej zasady. Uzasadniając przypisywany jej charakter, stwierdził: „,[... niejasność przepisu może uzasadniać stwierdzenie jego niezgodności z Konstytucją, o ile jest tak daleko posunięta, że wynikających z niej rozbieżności nie da się usunąć za pomocą zwyczajnych środków" (wyrok TK z dnia 3 grudnia 2002 r., P 13/02, Legalis nr 55492). Co więcej, wskazywał również, że to na ustawodawcy ciąży „obowiązek tworzenia przepisów prawa możliwie najbardziej określonych w danym przypadku, zarówno pod względem ich treści, jak i formy. Na oba wymiary określoności prawa składają się kryteria [...]: precyzyjność regulacji prawnej, jasność przepisu prawa oraz jego legislacyjna poprawność (wyrok TK z dnia 29 października 2009 r., KP 3/09, Legalis nr 175631).

${ }^{23} \mathrm{Z}$ jednej strony zauważa on, iż ,trzeba zgodzić się ze stwierdzeniem, że przepisy określające sankcje prawne wymagają ścisłej interpretacji, co oznacza, że w takich przypadkach zasadniczą rolę należałoby przypisać językowym dyrektywom wykładni”, natomiast z drugiej - odchodząc od dyrektyw wykładni językowej - skłania się ku funkcjonalnemu pojmowaniu analizowanych przepisów. 
przez prawodawcę w art. 41 u.d.p. Nadmienić należy, iż w dotychczas dominującej linii orzeczniczej zauważano, iż:

[...] przepisy regulujące administracyjną odpowiedzialność i będące podstawą wymierzenia administracyjnej kary pieniężnej muszą w sposób wyraźny wynikać z ustawy. Niedopuszczalna jest bowiem w demokratycznym państwie prawnym (art. 2 Konstytucji RP) sytuacja, w której dany podmiot będzie ponosił odpowiedzialność administracyjną za okoliczności niewynikające wprost z powszechnie obowiązujących przepisów prawa ${ }^{24}$.

$\mathrm{Z}$ uwagi na to przy ustalaniu odpowiedzialności w oparciu o art. 140aa p.r.d. należy posiłkować się dyrektywami wykładni literalnej, jednocześnie odrzucając dopuszczalność rozszerzającej interpretacji przedmiotowej regulacji25.

Nie można również zgodzić się z poglądami składu orzekającego NSA, według której dopuszczalność posiłkowania się regulacją r.w.t. w sprawach o nałożenie kary pieniężnej za przejazd pojazdem nienormatywnym wynikać by miała z charakteru dyrektywy 96/53, która została implementowana treścią wskazanego rozporządzenia. Wątpliwości nie powinien budzić fakt, iż dyrektywa 96/53 ma na celu zmniejszenie różnic pomiędzy normami transportowymi, odnoszącymi się do maksymalnych wymiarów oraz ciężarów, obowiązującymi w krajach członkowskich Unii Europejskiej, co zgodnie z motywem trzecim dyrektywy może pozytywnie wpłynąć na warunki konkurencji oraz niwelować przeszkody w swobodnym ruchu pomiędzy państwami członkowskimi. Słusznie również podnosi skład orzekający, iż normy dyrektywy 96/53 odnoszące się do ciężarów (określone w załączniku I) obowiązują jako normy transportowe i nie mogą być traktowane jako normy produkcji (które zgodnie z jej art. 1 mają zostać ustanowione w oddzielnej dyrektywie). Jednakże charakter norm dyrektywy wydaje się uzasadniać niedopuszczalność posiłkowania się przepisami r.w.t. Przede wszystkim to właśnie z uwagi na fakt, iż określone $\mathrm{w} \S 5$ rozporządzenia dozwolone naciski różnych typów osi pojazdów nie mają charakteru norm technicznych, lecz norm załadunku, a tym samym nie odnoszą się do pojazdów jako takich. Jednocześnie samo r.w.t. niewątpliwie zostało ustanowione w celu określenia pewnych warunków technicznych, jakim powinny odpowiadać pojazdy na etapie ich produkcji i późniejszego dopuszczania do ruchu $^{26}$, co pozwala na stwierdzenie, że prawodawca w nieprawidłowy sposób

${ }^{24}$ Wyrok NSA z dnia 1 lutego 2018 r., II GSK 3289/17, Legalis nr 175741. Zob. także: wyrok NSA z dnia 12 października 2017 r., II GSK 3292/15, Legalis nr 1698684; wyrok NSA z dnia 23 marca 2016 r., II GSK 2172/14, Legalis nr 1509704; wyrok NSA z dnia 18 lipca 2017 r., II GSK 2670/15, Legalis nr 1663997.

${ }_{25}$ Por. wyrok NSA z dnia 1 lutego 2018 r., II GSK 3289/17, Legalis nr 175741; wyrok NSA z dnia 12 października 2017 r., II GSK 3292/15, Legalis nr 1698684.

26 Takie poglądy odnośnie do charakteru r.w.t. odnaleźć można w stanowiskach zajmowanych przez niektórych komentatorów przepisów o ruchu drogowym. Por. R.A. Stefański, Prawo o ruchu drogowym. Komentarz, LEX/el. 2008, komentarz do art. 66; W. Kotowski, Prawo o ruchu drogowym. 
implementował dyrektywę 96/53. Dlatego też niemożliwe wydaje się zaaprobowanie poglądów NSA w tym zakresie, ponieważ sam fakt, iż r.w.t. transponuje do polskiego porządku prawnego przepisy dyrektywy nie uzasadnia dopuszczalności posiłkowania się jego przepisami podczas ustalania nienormatywności pojazdu w sprawach o nałożenie kary pieniężnej za przejazd pojazdem nienormatywnym.

Mimo faktu, że poglądy wyrażone przez skład orzekający NSA w glosowanym orzeczeniu wydają się być nie do zaaprobowania, należy zwrócić uwagę, iż dostrzega on nieprawidłowości spornej w sprawie regulacji. Niewątpliwie obecnie obowiązujące regulacje prawne w znacznym stopniu ograniczają krąg podmiotów, które mogą zostać pociągnięte do odpowiedzialności z tytułu wykonywania przejazdu pojazdem o nienormatywnych naciskach, co wydaje się być stanem niepożądanym ${ }^{27}$. Zarówno sąd pierwszej instancji, jak i NSA w przedmiotowej sprawie słusznie zwróciły uwagę na fakt, że bezpieczeństwo ruchu drogowego oraz konieczność zapewnienia ochrony stanu technicznego dróg (a także infrastruktury drogowej) wymagają pełnej regulacji. Jednakże osiągnięcie postulowanego przez sądy obu instancji stanu wydaje się w tej sytuacji wymagać ingerencji prawodawcy (przy jednoczesnej niedopuszczalności usunięcia powstałej luki w inny sposób). Dlatego też de lege ferenda należałoby wnioskować zarówno o przeniesienie treści $\S 5$ r.w.t. do innego aktu prawnego, jak i o zmianę definicji pojazdu nienormatywnego. W pierwszym przypadku zasadne byłoby przeniesienie wskazanych treści bezpośrednio do u.d.p. i właściwego przedmiotowo w tej kwestii art. 41 bądź ustanowienie upoważnienia do wydania stosownego rozporządzenia na podstawie art. 41 u.d.p., co w konsekwencji mogłoby wyeliminować rozbieżności i wątpliwości interpretacyjne w zakresie dopuszczalnych nacisków różnych typów osi na

Komentarz, Warszawa 2011, s. 606-609; Ł. Malinowski, Prawo o ruchu drogowym. Komentarz, LEX/el. 2012, komentarz do art. 66. Charakter przedmiotowego rozporządzenia wyprowadzić można również za pomocą dyrektyw wykładni systemowej. Upoważnienie do ustanowienia r.w.t. znajduje się w dziale III p.r.d. zatytułowanym „Pojazdy” w rozdziale 1 „Warunki techniczne pojazdów”. Przepisy przywołanego rozdziału p.r.d. niewątpliwie ustanawiają normy dotyczące parametrów technicznych pojazdów jako takich, nie zaś normy transportowe. Jednocześnie podnieść należy, że za taką wykładnią art. 66 ust. 5 p.r.d. przesądza fakt, iż treść upoważnienia do ustanowienia r.w.t. pozostała do dzisiaj nie zmieniona (w pierwotnym brzmieniu p.r.d. miała ona bowiem taką samą treść, zob. p.r.d. w brzmieniu pierwotnym: Dz.U. 1997, nr 98, poz. 602).

27 Jak słusznie zauważa się w orzecznictwie: „[...] największe spustoszenie na drogach czynią pojazdy o niewłaściwym, nierównomiernym rozłożeniu ładunku na poszczególne osie, a decydującym czynnikiem oceny normatywności pojazdu muszą być w istocie naciski wywierane właśnie na poszczególne osie pojazdu. [...] Jest to [konieczność ochrony dróg - P.Z.] podyktowane dbałością o ochronę stanu technicznego dróg, jako że przeciążenie chociażby jednej z osi ponad dopuszczalną wartość techniczną drogi może skutkować negatywnie na jej stan [...], a pojazd uczestniczący w ruchu ma być tak zbudowany, wyposażony i utrzymany, aby korzystanie z niego nie powodowało niszczenia drogi”. Por. wyrok WSA w Warszawie z dnia 12 kwietnia 2017 r., VI SA/Wa 2679/16, Legalis nr 1603416; wyrok WSA w Warszawie z dnia 8 listopada 2017 r., VI SA/Wa 528/17, Legalis nr 1710739. 
drogi publiczne. W drugim przypadku należałoby postulować o zmianę definicji $\mathrm{z}$ art. 2 pkt 35a p.r.d. polegającą na usunięciu sformułowania „przewidziane dla danej drogi". Wniosek ten uzasadnia przede wszystkim dyrektywa 96/53, która (jak słusznie zwrócił na to uwagę skład orzekający NSA) nie ustanawia poszczególnych norm nacisków dla konkretnych rodzajów dróg publicznych. Zabieg taki nie powinien powodować kolizji z treścią załącznika nr 1 do p.r.d. (o ile prawodawca zaktualizuje jego treść zgodnie $\mathrm{z}$ wyrokiem $\mathrm{TSUE}^{28}$ ), a wydając zezwolenie na przejazd pojazdem nienormatywnym, dopuszczalne będzie uwzględnienie możliwych ograniczeń na drogach, przez które przebiegać będzie jego trasa.

\section{PODSUMOWANIE}

Niewątpliwie ochrona dróg publicznych oraz dbałość o zachowanie odpowiedniego bezpieczeństwa ruchu drogowego wymagają od ustawodawcy ustanowienia kompleksowych i klarownych regulacji. Takiej samej jasności i precyzyjności wymagają przepisy, na podstawie których możliwe jest nakładanie lub wymierzanie jakichkolwiek represji w stosunku do podmiotów znajdujących się poza strukturą władzy publicznej (w tym podmiotów administrowanych). Przenosząc te uwagi na grunt glosowanego orzeczenia, stwierdzić można, iż Naczelny Sąd Administracyjny w niezasługujący na aprobatę sposób dokonał interpretacji przepisów odnoszących się do odpowiedzialności na gruncie art. 140aa p.r.d. Sąd powinien przede wszystkim na początku dążyć do poprawnego ustalenia przepisów, na podstawie których możliwe jest ustalenie norm określających maksymalny dopuszczalny nacisk osi pojazdu na daną kategorię drogi publicznej, gdyż w obecnym stanie prawnym niedopuszczalne jest karanie za przekroczenie norm nacisku na napędowej osi wielokrotnej czy też na osi nienapędowej (bez znaczenia, czy jest ona pojedyncza czy wielokrotna). Co więcej, skład orzekający NSA winien mieć na uwadze, iż represyjna funkcja administracyjnych kar pieniężnych nie powinna być dominująca, gdyż ,celem pierwszoplanowym kar administracyjnych jest funkcja ochronna w stosunku do porządku administracyjnego, następnie funkcja redystrybucyjna, a na końcu represyjna" ${ }^{29}$. Nadmienić należy, że obowiązujące aktualnie regulacje, zarówno u.d.p., p.r.d., jak i wydanych na ich podstawie aktów wykonawczych, tworzą w pewnych zakresach niespójny i chaotyczny zbiór, z których niewątpliwie trudno jest niejednokrotnie odkodować zamiar ustawodawcy, który w teorii dąży do pełnej regulacji przedmiotowej problematyki. Dlatego uzasadnione wydaje się być postulowanie o przeprowadzenie rewizji wspomnianych aktów normatywnych w celu uporządkowania umiejscowienia niektórych przepisów tak, by

${ }^{28}$ Wyrok TSUE z dnia 21 marca 2019 r., C-127/17, Legalis nr 1889073.

${ }^{29}$ Por. wyrok TK z dnia 1 lipca 2014 r., SK 6/12, Legalis nr 981748. 
zakres odpowiedzialności za delikt administracyjny sankcjonowany w art. 140aa p.r.d. jak najbardziej adekwatnie sprzyjał ochronie stanu dróg publicznych oraz bezpieczeństwu w ich granicach.

\section{BIBLIOGRAFIA}

\section{Literatura}

Kasznica S., Polskie prawo administracyjne, Poznań 1946.

Kijowski D.R., [w:] System Prawa Administracyjnego, t. 7: Prawo administracyjne materialne, red. R. Hauser, Z. Niewiadomski, A. Wróbel, Warszawa 2017.

Kijowski D.R., Pozwolenia w administracji publicznej, Białystok 2000.

Kotowski W., Prawo o ruchu drogowym. Komentarz, Warszawa 2011.

Król-Bogomilska M., Administracyjne kary pieniężne - kierunki rozwoju, [w:] Prawo wobec problemów społecznych. Księga jubileuszowa Profesor Eleonory Zielińskiej, red. B. Namysłowska-Gabrysiak, K. Syroka-Marczewska, A. Walczak-Żochowska, Warszawa 2016.

Malinowski Ł., Prawo o ruchu drogowym. Komentarz, LEX/el. 2012.

Mały słownik języka polskiego, red. S. Skorupka, H. Auderska, Z. Łempicka, Warszawa 1969.

Nowicki D.K., Peszkowski S., Kilka uwag o szczególnym charakterze administracyjnych kar pieniężnych, [w:] Administracyjne kary pieniężne w demokratycznym państwie prawa, red. M. Błachucki, Warszawa 2015.

Sobieralski K., Kara za zajęcie pasa drogowego, Wrocław 2015.

Stefański R.A., Prawo o ruchu drogowym. Komentarz, LEX/el. 2008.

Wierczyński G., Redagowanie i ogłaszanie aktów normatywnych. Komentarz, Warszawa 2016.

Zaborniak P., Prawo dostępu do dóbr publicznych, Warszawa 2015.

Zaborniak P., Ustawa o drogach publicznych. Komentarz, Warszawa 2010.

Zirk-Sadowski M., [w:] System Prawa Administracyjnego, t. 4: Wyktadnia w prawie administracyjnym, red. R. Hauser, Z. Niewiadomski, A. Wróbel, Warszawa 2012.

\section{Akty prawne}

Dyrektywa Rady nr 96/53/WE z dnia 25 lipca 1996 r. ustanawiająca dla niektórych pojazdów drogowych poruszających się na terytorium Wspólnoty maksymalne dopuszczalne wymiary w ruchu krajowym i międzynarodowym oraz maksymalne dopuszczalne obciążenia w ruchu międzynarodowym (Dz.Urz. UE L nr 235, s. 59).

Konstytucja Rzeczypospolitej Polskiej z dnia 2 kwietnia 1997 r. (Dz.U. nr 78, poz. 483 ze zm.).

Rozporządzenie Rady Ministrów z dnia 16 lipca 2002 r. w sprawie autostrad płatnych (Dz.U. 2014, poz. 45).

Rozporządzenie Ministra Infrastruktury z dnia 31 grudnia 2002 r. w sprawie warunków technicznych pojazdów oraz zakresu ich niezbędnego wyposażenia (t.j. Dz.U. 2016, poz. 2022 ze zm.).

Rozporządzenie Ministra Transportu z dnia 31 lipca 2007 r. w sprawie okresowych ograniczeń oraz zakazu ruchu niektórych rodzajów pojazdów na drogach (Dz.U. 2013, poz. 839).

Ustawa z dnia 21 marca 1985 r. o drogach publicznych (t.j. Dz.U. 2007, poz. 115 ze zm.; t.j. Dz.U. 2018, poz. 2068 ze zm.). 
Ustawa z dnia 20 czerwca 1997 r. - Prawo o ruchu drogowym (Dz.U. 1997, nr 98, poz. 602; t.j. Dz.U. 2018, poz. 1990 ze zm.).

Ustawa z dnia 27 października 1997 r. o autostradach płatnych i Krajowym Funduszu Drogowym (Dz.U. 2017, poz. 1057 z późn. zm.).

Ustawa z dnia 27 kwietnia 2001 r. - Prawo ochrony środowiska (t.j. Dz.U. 2018, poz. 799 ze zm.). Ustawa z dnia 6 września 2001 r. o transporcie drogowym (t.j. Dz.U. 2017, poz. 2200 ze zm.).

Ustawa z dnia 19 sierpnia 2011 r. o przewozie towarów niebezpiecznych (t.j. Dz.U. 2019, poz. 382).

\section{Orzecznictwo}

Wyrok NSA z dnia 23 marca 2016 r., II GSK 2172/14, Legalis nr 1509704.

Wyrok NSA z dnia 18 lipca 2017 r., II GSK 2670/15, Legalis nr 1663997.

Wyrok NSA z dnia 12 października 2017 r., II GSK 3292/15, Legalis nr 1698684.

Wyrok NSA z dnia 1 lutego 2018 r., II GSK 3289/17, Legalis nr 175741.

Wyrok TK z dnia 3 grudnia 2002 r., P 13/02, Legalis nr 55492.

Wyrok TK z dnia 29 października 2009 r., KP 3/09, Legalis nr 175631.

Wyrok TK z dnia 1 lipca 2014 r., SK 6/12, Legalis nr 981748.

Wyrok TSUE z dnia 21 marca 2019 r., C-127/17, Legalis nr 1889073.

Wyrok WSA w Kielcach z dnia 16 czerwca 2011 r., II SA/Ke 247/11, Legalis nr 377213.

Wyrok WSA w Warszawie z dnia 12 kwietnia 2017 r., VI SA/Wa 2679/16, Legalis nr 1603416.

Wyrok WSA w Warszawie z dnia 8 listopada 2017 r., VI SA/Wa 528/17, Legalis nr 1710739.

\section{SUMMARY}

The subject of this gloss is the judgement of the Supreme Administrative Court in case of imposing an administrative monetary penalty for movement of non-normative vehicle on public road in which the judgement of Voivodeship Administrative Court in Warsaw was set aside and return the case for re-examination. In this judgement, the formation of the court, in a way going against the previous line of jurisprudence, stated that decoding the meaning of "axle load provided for a given road" may result from the application of a functional interpretation driectives, and thus, the basis for its determination may also be the regulation of the Minister of Infrastructure of 31 December 2002 on the Technical Conditions of Vehicles and the Scope of Their Necessary Equipment. The content of the sentence itself and the reasons for the judgement do not allow for its approval, therefore the gloss has a critical character.

Keywords: non-normative vehicle; axle load; provisions on public roads; Law on Road Traffic 